\title{
Formulasi Tablet dengan Bahan Aktif Ekstrak Tumbuhan Obat Indonesia: Review
}

\author{
Adrian Suparman', Yasmiwar Susilawati ${ }^{*, 1}$, Anis Yohana Chaerunisa² \\ 1Departemen Biologi Farmasi, Fakultas Farmasi, Universitas Padjadjaran \\ 2Departemen Farmasetika dan Teknologi Farmasi, Fakultas Farmasi, Universitas Padjadjaran, \\ Jl. Raya Bandung Sumedang Km. 21 Jatinangor Sumedang 45360 \\ *Email: yasmiwar@unpad.ac.id
}

(Submit 15/2/2021, Revisi 9/5/2021, Diterima 10/8/2021, Terbit 14/8/2021)

\begin{abstract}
Abstrak
Penggunaan tumbuhan obat sebagai bahan aktif pada sediaan obat herbal telah banyak digunakan baik untuk upaya preventif, promotif dan kuratif. Sediaan obat herbal telah banyak digunakan oleh masyarakat dengan berbagai macam jenis dan bentuk sediaan. Salah satu bentuk sediaan obat, termasuk sediaan obat herbal, yang banyak dibuat dan digunakan adalah sediaan tablet, dimana keunggulan sediaan tablet adalah dosisnya yang tepat, stabil dalam penyimpanan, dan penggunaannya yang praktis. Review ini bertujuan untuk mengumpulkan literatur mengenai formulasi sediaan tablet dengan bahan aktif ekstrak tumbuhan di Indonesia. Pustaka primer yang digunakan pada review ini adalah jurnal mengenai formulasi tablet dengan bahan tumbuhan herbal Indonesia dengan rentang waktu publikasi antara tahun 2010-2020. Review disajikan dalam bentuk tabel yang berisi rangkuman dari Pustaka yang digunakan dan pembahasan dari hasil review. Dalam review juga dicantumkan mengenai metode dan eksipien yang digunakan pada masing-masing tumbuhan. Dari hasil review diketahui bahwa metode yang paling banyak digunakan adalah metode granulasi basah karena sifat granul yang dihasilkan lebih baik. Namun pemilihan metode disesuaikan dengan sifat ekstrak dan eksipien yang akan digunakan. Review ini diharapkan dapat menjadi referensi bagi peneliti maupun penulis dalam melakukan penelitian mengenai formulasi dengan bahan aktif ekstrak.
\end{abstract}

Kata kunci: Formulasi, Tablet, Ekstrak

\section{Latar Belakang}

Berdasarkan Peraturan Menteri Kesehatan No 6 Tahun 2016 mengenai Formularium Obat Herbal Asli Indonesia, disebutkan bahwa Obat Herbal Terstandar (OHT) merupakan "sediaan herbal yang telah distandardisasi bahan baku dan produk jadinya, harus memenuhi persyaratan aman dan mutu yang sesuai dengan persyaratan yang berlaku serta klaim khasiat dibuktikan secara ilmiah/praklinik". 
Selama 100 tahun terakhir, pengembangan dan produksi massal obat-obatan yang disintesis secara kimia telah merevolusi perawatan kesehatan di hampir semua negara. Namun, sebagian besar penduduk di negara berkembang masih mengandalkan praktisi tradisional dan obat-obatan herbal untuk perawatan utama mereka.

Alasan paling umum penggunaan obat tradisional adalah: harganya lebih terjangkau, lebih dekat dengan ideologi pasien, menghilangkan kekhawatiran tentang efek buruk dari obat-obatan kimia (sintetis), memuaskan keinginan untuk perawatan kesehatan yang lebih personal, dan memungkinkan akses publik yang lebih besar untuk informasi kesehatan. Penggunaan utama obat herbal adalah untuk promosi kesehatan dan terapi untuk kondisi kronis, yang berlawanan dengan efek yang mengancam keselamatan pasien. Ketika obat konvensional tidak lagi efektif dalam pengobatan penyakit, penggunaan obat tradisional meningkat, seperti pada kanker lanjut dan dalam menghadapi penyakit menular baru. Selain itu, obat-obatan tradisional secara luas dianggap alami dan aman (tidak beracun). Walaupun pandangan tersebut belum tentu benar. ${ }^{1,2}$

Penggunaan zat aktif berupa tanaman pada sediaan obat dimaksudkan sebagai alternatif pada pengobatan bila pengobatan dengan zat aktif berupa bahan kimia sintetis tidak dapat menimbulkan efek yang diharapkan.

Tablet merupakan sediaan obat yang umum dan diminati oleh konsumen karena pemakaiannya praktis, ukuran dan dosisnya tepat, biaya produksi murah, pengemasan mudah, dan tahan penyimpanan. ${ }^{3}$

Beberapa keuntungan sediaan tablet diantaranya sediaan lebih kompak, biaya pembuatannya lebih murah, dosisnya tepat, pengemasannya mudah, sehingga penggunaannya lebih praktis jika dibandingkan dengan sediaan lain ${ }^{4}$.

Pada pembuatan tablet, terdapat tiga metode yang sering digunakan yaitu: granulasi basah, granulasi kering dan kempa langsung.

Granulasi basah merupakan metode pembuatan tablet dimana terdapat adanya penambahan bahan pengikat berbentuk larutan/mucilago yang bersifat hidrofobik/hidrofilik. ${ }^{5}$ Biasanya pembuatan tablet dengan metode granulasi basah dilakukan untuk zat aktif dengan laju alir yang buruk dan juga tahan terhadap adanya air dan pemanasan. ${ }^{6}$ 
Sementara dalam proses pembuatan tablet dengan metode granulasi kering, kompresi campuran serbuk dilakukan tanpa menggunakan bantuan panas ataupun pelarut. Dua langkah dasar dalam granulasi kering adalah: pembentukan material yang kompak dengan kompresi, dan kemudian menggiling massa cetak untuk mendapatkan granul. Terdapat dua metode yang sering digunakan dalam pembuatan tablet dengan proses granulasi kering. Metode yang paling umum digunakan adalah slugging, di mana campuran yang mengandung zat aktif dikompresi dan menghasilkan tablet atau slug, kemudian diayak kembali untuk mendapatkan ukuran granul yang diinginkan. ${ }^{7}$ Pembuatan tablet dengan metode kempa langsung dilakukan pada zat aktif yang memiliki sifat tidak tahan pemanasan dan air. Selain itu, untuk meningkatkan sifat alir zat aktif maupun massa cetak, zat aktif perlu dipadukan dengan eksipien yang memiliki sifat alir yang baik. Sehingga massa cetak yang dihasilkan dapat menghasilkan tablet dengan hasil evaluasi yang baik.

Review ini bertujuan untuk mengumpulkan literatur hasil penelitian mengenai formulasi tablet dengan bahan ekstrak sebagai zat aktifnya. Review yang dibuat berisi: tanaman sebagai bahan aktif, metode formulasi tablet, eksipien yang digunakan dan produk solid yang dihasilkan.

\section{Metode}

Penelitian dilakukan menggunakan metode literature research. Penelusuran jurnal yang dipublikasi di Indonesia sebagai pustaka primer dicari dengan kata kunci "formulasi tablet dengan bahan ekstrak", "formulasi tablet herbal", dan "tablet herbal formulation" dengan jangka waktu publikasi jurnal antara tahun 2010-2020. Selain itu terdapat pustaka sekunder berupa buku dan jurnal internasional yang dipublikasi sebelum tahun 2010 (1) untuk mendukung teori dari review.

\section{Hasil}

Berdasarkan penelusuran pustaka yang telah dilakukan, didapatkan data beberapa jurnal yang membahas mengenai formulasi tablet dengan bahan aktif tumbuhan herbal dengan metode formulasi dan eksipien yang berbeda-beda. Didapatkan 30 jurnal yang menjadi sumber dalam pembuatan review dan dirangkum dalam tabel berikut: 
Tabel 1. Riset Formulasi Tablet dari Ekstrak Tumbuhan Obat Indonesia

\begin{tabular}{|c|c|c|c|c|c|c|}
\hline No & Tanaman & $\begin{array}{c}\text { Bahan } \\
\text { /zat aktif }\end{array}$ & $\begin{array}{l}\text { Metode } \\
\text { formulasi }\end{array}$ & Eksipien & Produk & $\begin{array}{c}\text { Nomor } \\
\text { Referensi }\end{array}$ \\
\hline 1 & $\begin{array}{c}\text { Daun maja (Aegle } \\
\text { marmelos }(\mathrm{L} .) \\
\text { Correa }\end{array}$ & $\begin{array}{l}\text { ekstrak } \\
\text { etanol } \\
\text { kental }\end{array}$ & $\begin{array}{c}\text { granulasi } \\
\text { basah }\end{array}$ & $\begin{array}{c}\text { Na CMC (pengikat) } \\
\text { Avice; } 102 \text { (pengisi) } \\
\text { Pati jagung } \\
\text { (penghancur) } \\
\text { Mg stearat } \\
\text { (pelincir) } \\
\text { Mg karbonat } \\
\text { (absorben) } \\
\text { Talk (antilekat) }\end{array}$ & tablet & [8] \\
\hline 2 & $\begin{array}{l}\text { Kunyit (Curcuma } \\
\text { domestica Val) }\end{array}$ & $\begin{array}{l}\text { ekstrak } \\
\text { kental } \\
\text { kunyit }\end{array}$ & $\begin{array}{c}\text { granulasi } \\
\text { basah }\end{array}$ & $\begin{array}{c}\text { Aerosil } \\
\text { (penghancur) } \\
\text { Laktosa (pengisi) } \\
\text { Gelatin (pengikat) } \\
\text { Mg stearat } \\
\text { (pelincir) } \\
\text { Akuades } \\
\text { (pembasah) }\end{array}$ & tablet & [9] \\
\hline 3 & $\begin{array}{l}\text { Daun gedi } \\
\text { hijau } \\
\text { (Abelmoschus } \\
\text { manihot (L.) }\end{array}$ & $\begin{array}{l}\text { ekstrak } \\
\text { etanol } \\
\text { kering }\end{array}$ & $\begin{array}{c}\text { granulasi } \\
\text { basah }\end{array}$ & $\begin{array}{c}\text { Amilum manihot } \\
\text { (pengisi) } \\
\text { Gelatin (pengikat) } \\
\text { Mg stearat } \\
\text { (pelincir) } \\
\text { Talk (pelincir) }\end{array}$ & tablet & [10] \\
\hline 4 & $\begin{array}{c}\text { Meniran } \\
\text { (Phyllanthus niruri } \\
\text { L.) }\end{array}$ & $\begin{array}{l}\text { ekstrak } \\
\text { kering }\end{array}$ & $\begin{array}{c}\text { kempa } \\
\text { langsung }\end{array}$ & $\begin{array}{c}\text { Laktosa } \\
\text { Avicel } 102 \text { dan } \\
\text { Amprotab (pengisi) } \\
\text { Mg stearat } \\
\text { (pelincir) } \\
\text { Talk (pelincir) } \\
\text { Aerosil (absorben) }\end{array}$ & tablet & [11] \\
\hline
\end{tabular}




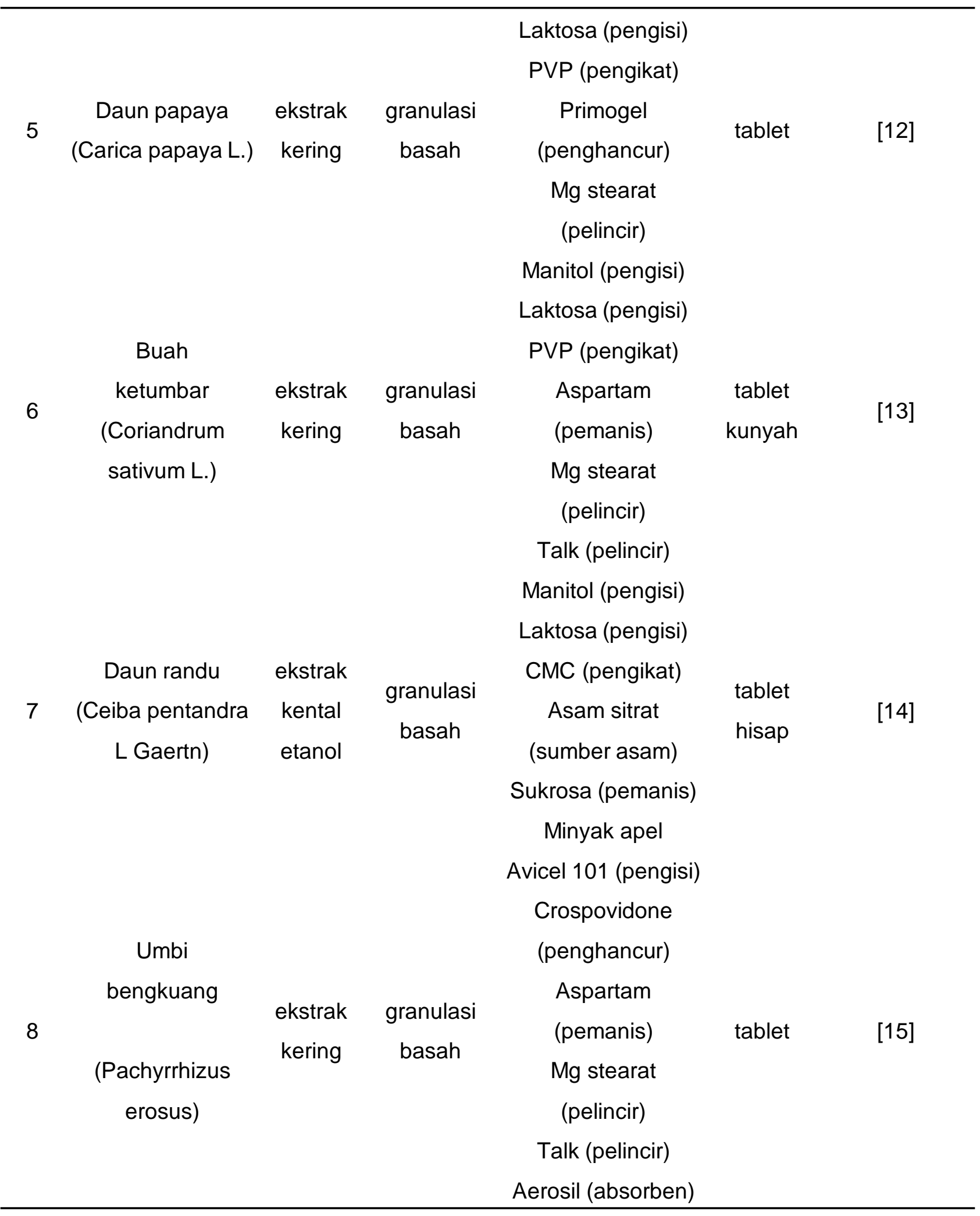




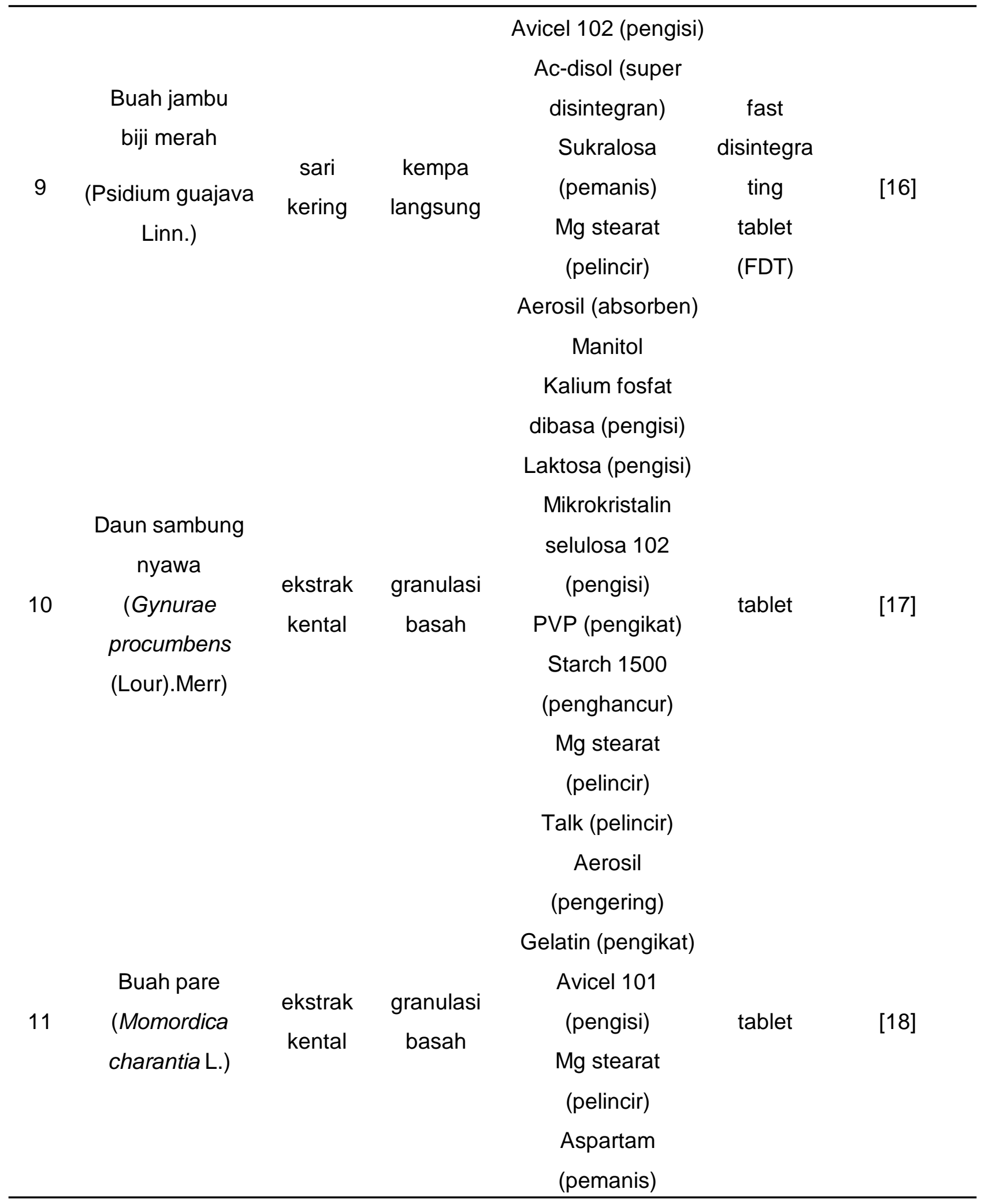




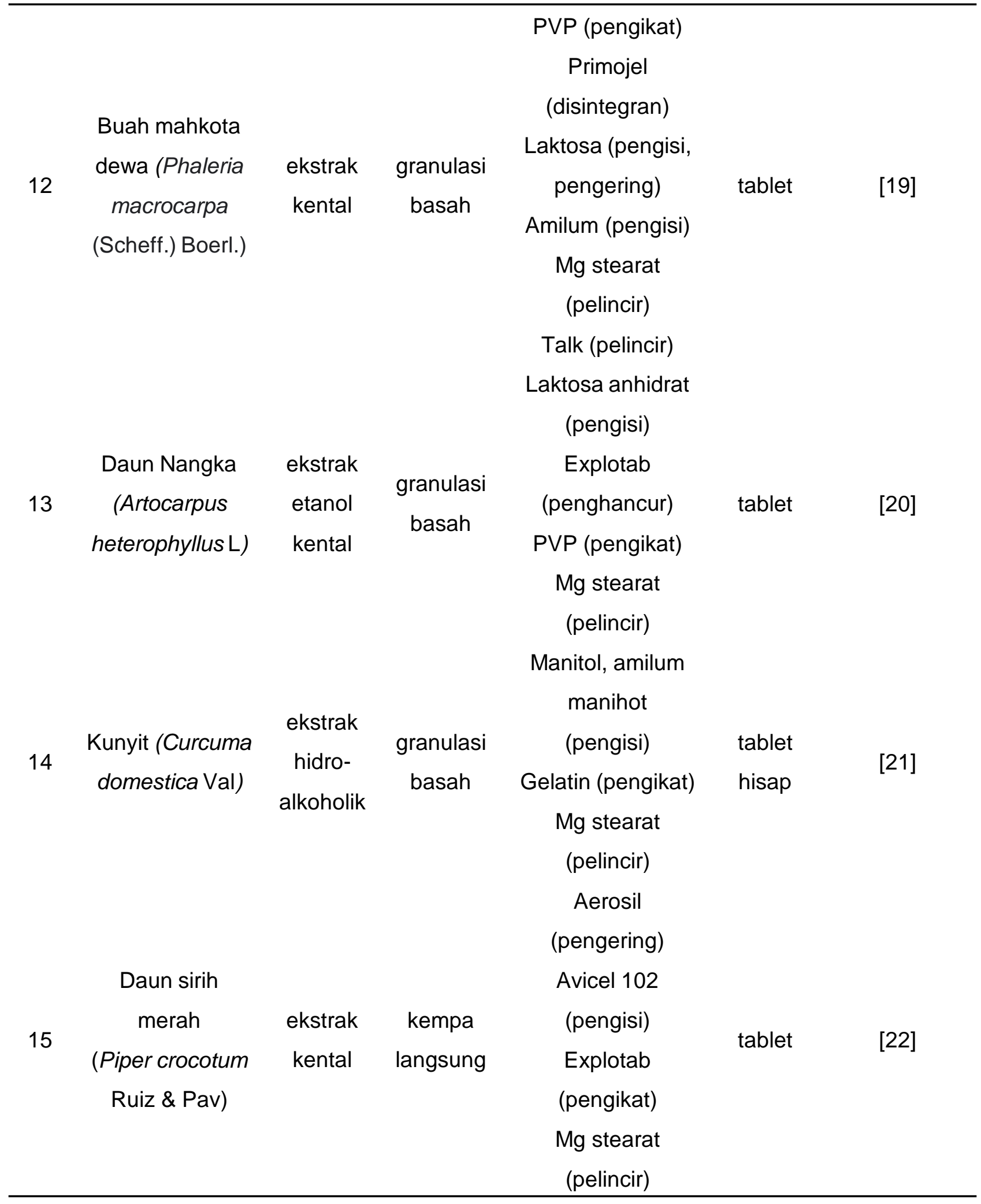




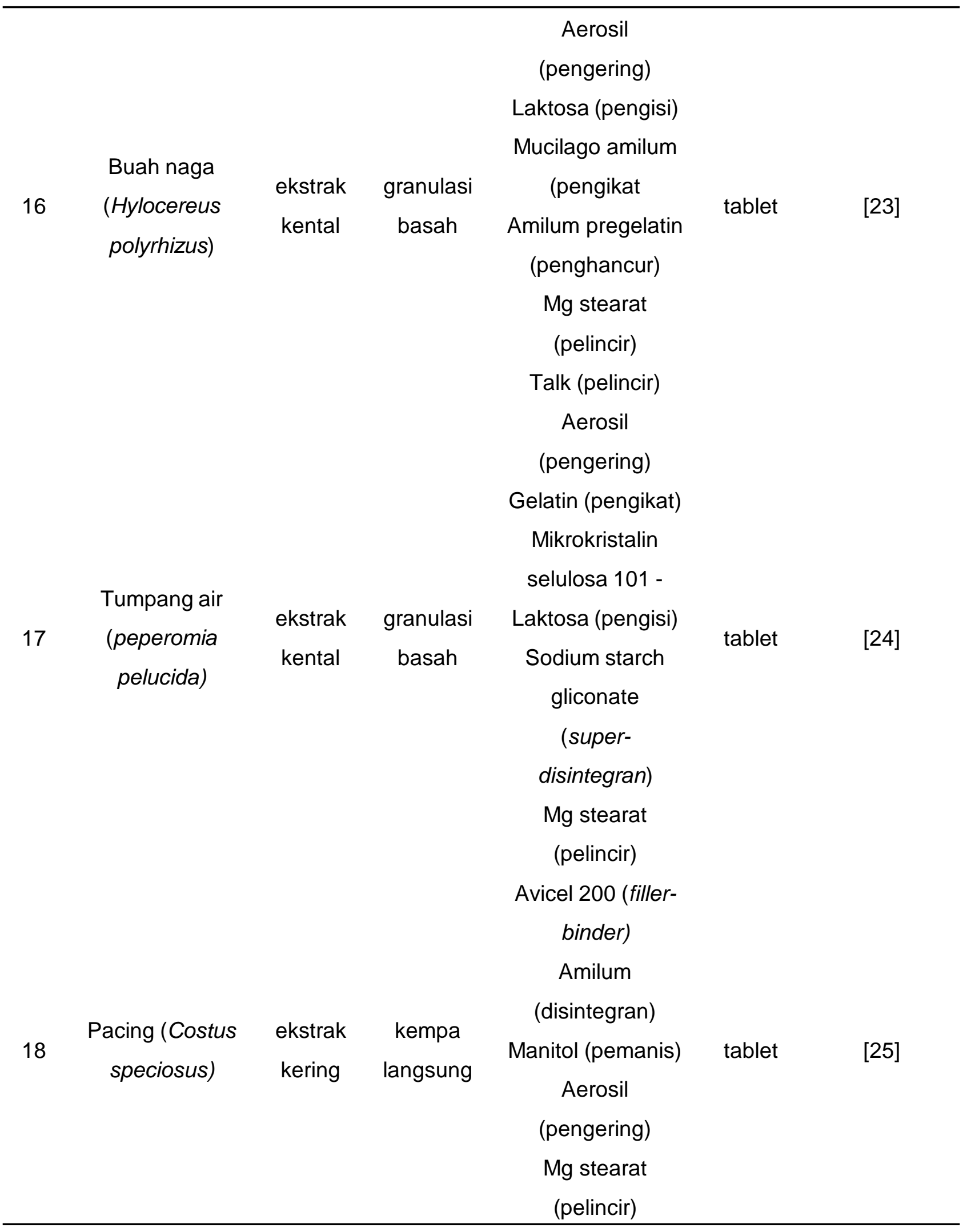




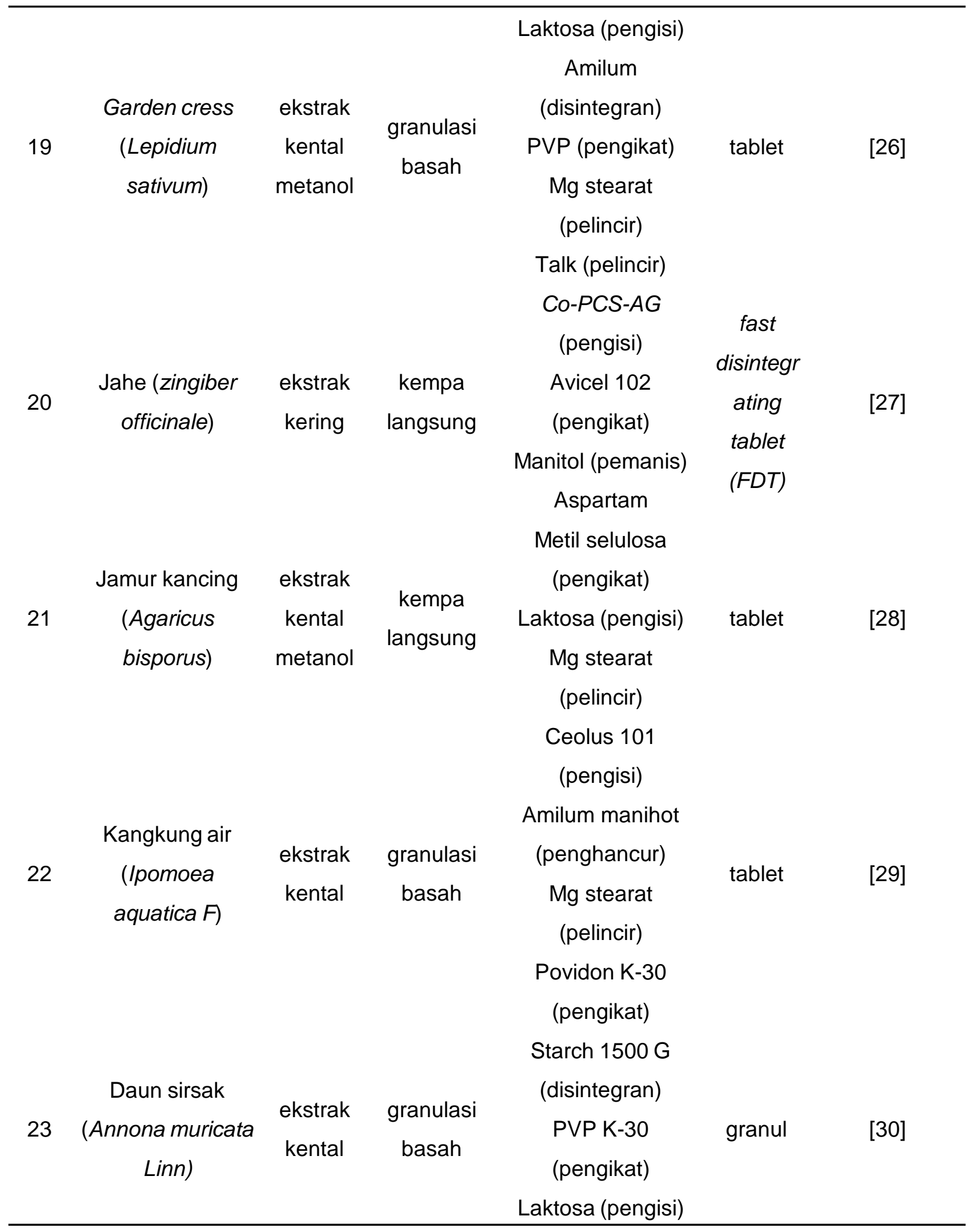




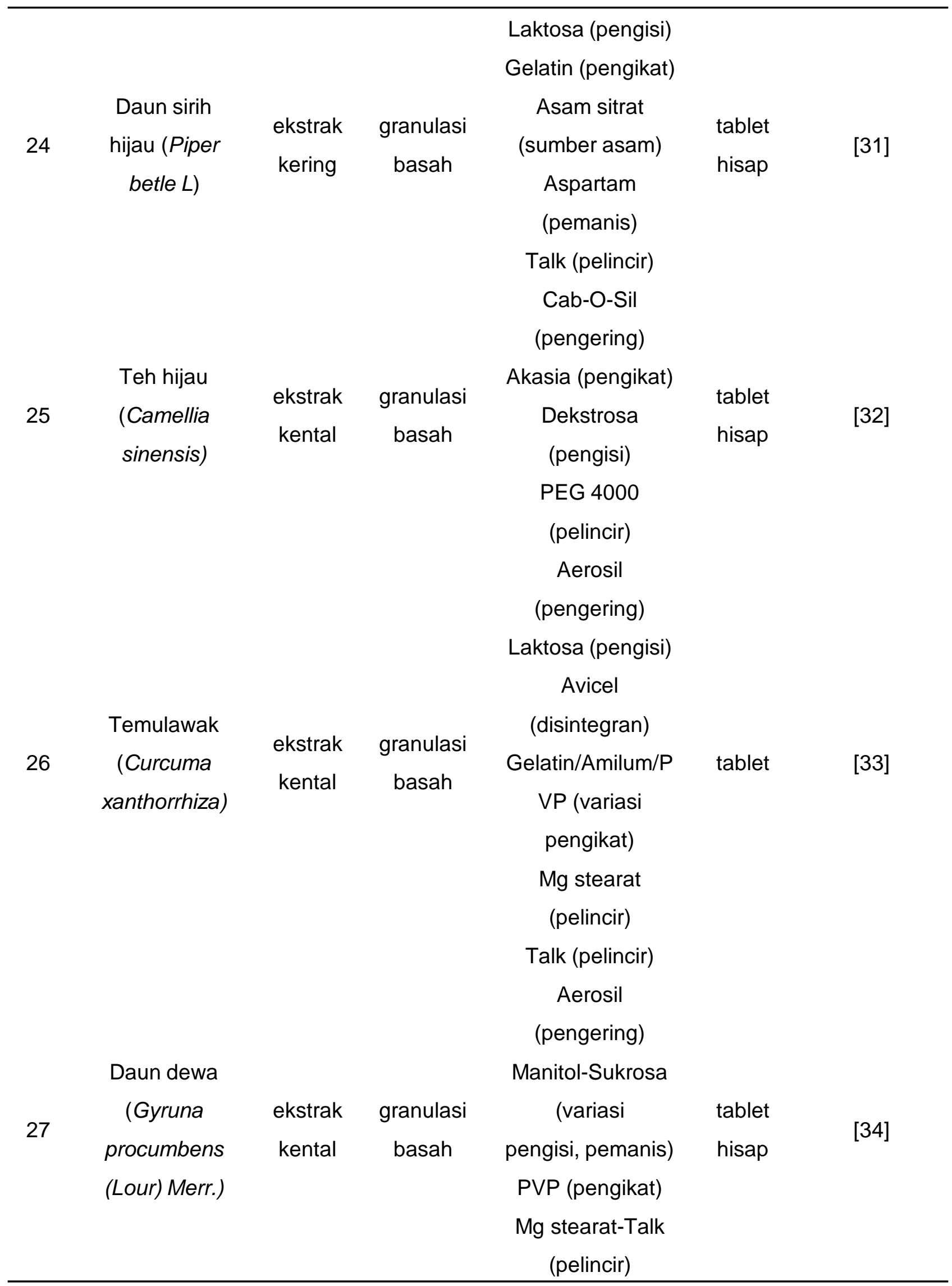




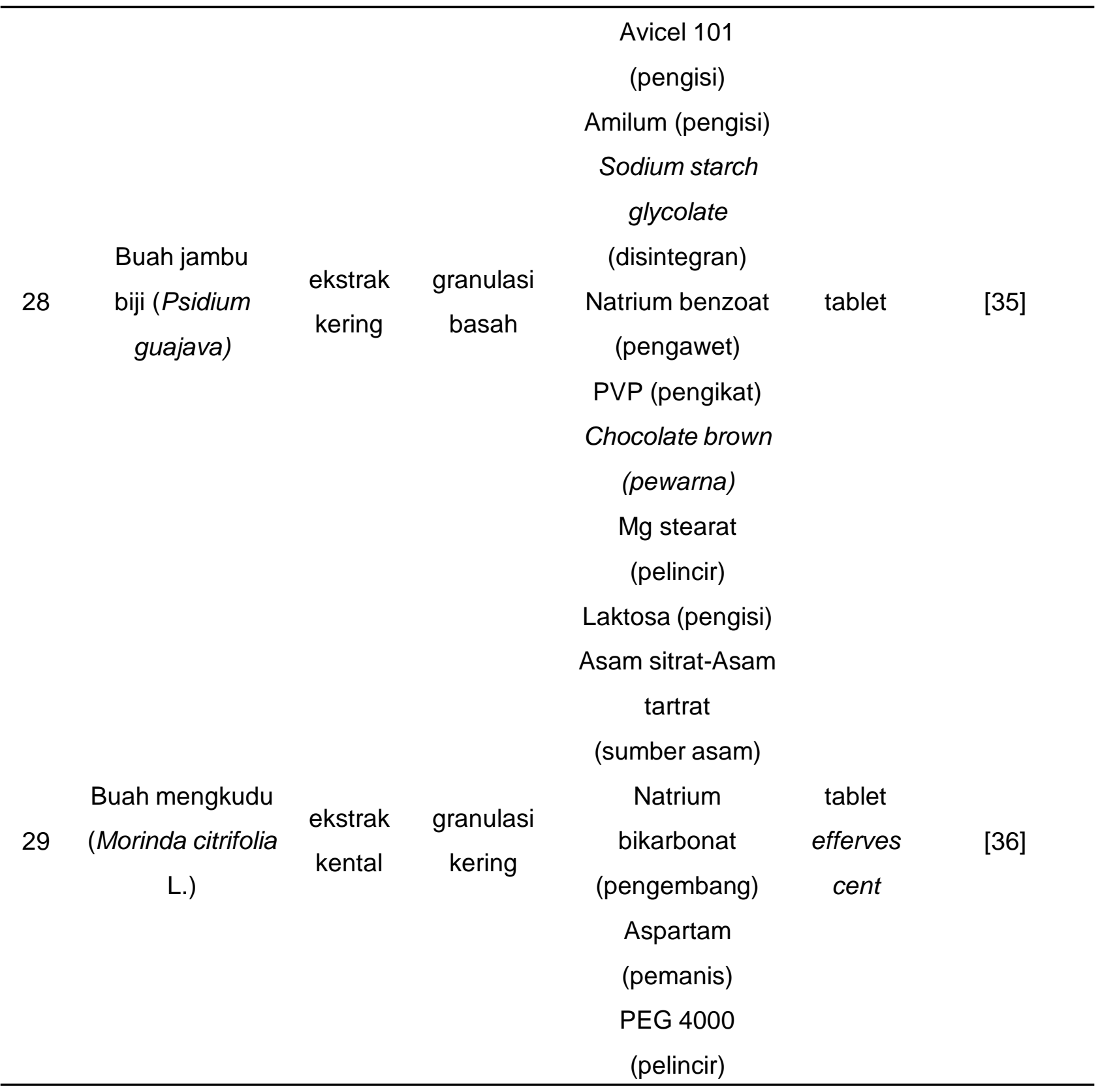




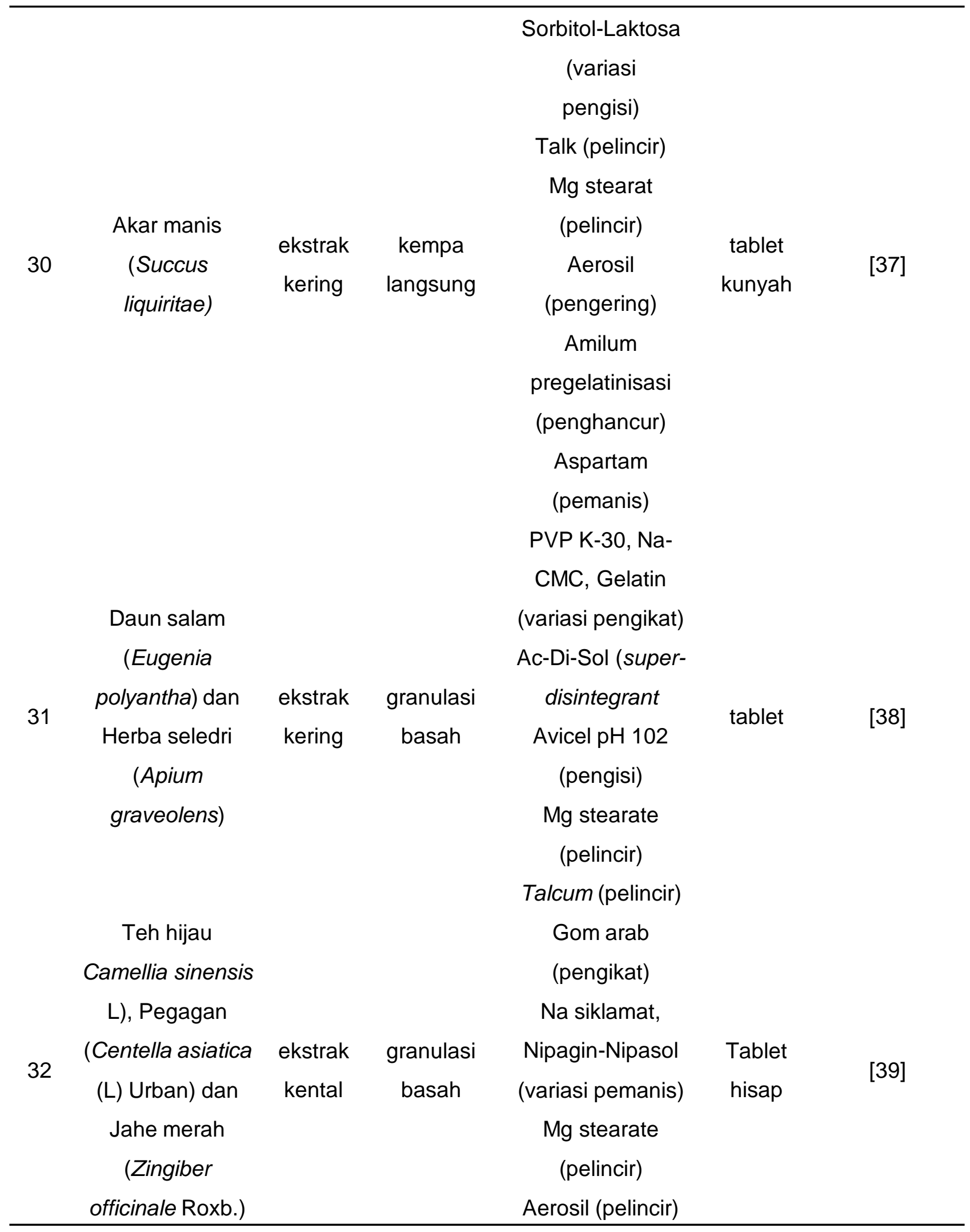




\section{Diskusi}

Dari hasil penelusuran pustaka, didapatkan hasil bahwa dari 30 jurnal yang dijadikan sebagai sumber penulisan review, pembuatan tablet dengan bahan ekstrak tanaman banyak dilakukan dengan metode granulasi basah (24 jurnal) dan kempa langsung ( 7 jurnal). Metode granulasi basah banyak digunakan pada formulasi sediaan tablet dengan zat aktif berupa tanaman (dalam bentuk ekstrak) karena ekstrak memiliki laju alir yang kurang baik jika dibandingkan dengan zat aktif lain dalam bentuk serbuk, dimana laju alir berpengaruh terhadap kemampuan aliran granul saat dikempa. Campuran granul yang dihasilkan dari pembuatan tablet dengan metode granulasi basah memiliki laju alir yang baik. Selain itu dalam pembuatan tablet dengan metode granulasi basah, kompresibilitas dan daya ikat dari granul yang dihasilkan dapat lebih baik. Karena pencampuran antara pengikat dan bahan lainnya lebih memungkinkan untuk menghasilkan granul dengan daya ikat partikel yang lebih baik. Sedangkan pada metode granulasi kering maupun kempa langsung, pengikat yang digunakan merupakan bahan pengikat kering, dimana proses pencampuran dengan bahan lainnya dilakukan dengan pengadukan secara homogen, sehingga memiliki kemungkinan bahwa distribusi ukuran partikel, distribusi zat aktif dalam campuran dan daya ikat antar partikelnya tidak sebaik bila menggunakan pengikat basah.

Pada pembuatan tablet dengan metode kempa langsung memerlukan bahan eksipien yang memiliki daya alir dan kompresibilitas yang baik untuk menutupi kekurangan dari ekstrak tanaman sebagai zat aktif. Sehingga eksipien yang digunakan memerlukan biaya yang cukup tinggi karena memiliki berbagai macam fungsi, meskipun prosedur dan tahap yang dilakukan lebih singkat dibandingkan pada metode granulasi. Pada pembuatan tablet dengan metode kempa langsung dengan dosis zat aktif yang tinggi, sifat fisik dari granul yang dihasilkan, terutama sifat alir dan kompresibilitas, ditentukan oleh sifat zat aktif sendiri40. Karena banyaknya eksipien dan konsentrasinya menyesuaikan dengan dosis zat aktif dan bobot tablet yang dicetak. Efeknya adalah eksipien kurang mampu dalam menutupi kekurangan sifat dari zat aktif. Dimana pada zat aktif berupa ekstrak biasanya memiliki sifat alir dan kompresibilitas yang kurang baik.

Pada penelitian Winarti ${ }^{17}$ tentang formulasi sediaan tablet ekstrak Sambung Nyawa (Gynurae procumbens (Lour).Merr) dengan metode granulasi basah, dilakukan pembuatan tablet menggunakan eksipien: PVP (pengikat), Starch 1500 (penghancur), Mg stearat (pelincir), Talk (pelincir), dengan variasi pengisi (kalium fosfat, mikrokristalin selulosa dan laktosa) dan dibuat dalam 3 variasi formula. Hasil pengujian evaluasi sifat fisik granul menunjukkan bahwa granul yang dihasilkan memiliki sifat fisik yang baik untuk dikempa. Dimana pada evaluasi laju alir serbuk, ketiga formula menghasilkan hasil pengujian yang kohesif (3,23 gr/detik; 3,38 gr/detik; 3,75 gr/detik). Laju alir granul dipengaruhi oleh kelembaban dan daya ikat granul. 
Kelembaban granul yang dihasilkan dari ketiga formula menghasilkan hasil yang sesuai persyaratan. Sehingga granul dapat cepat mengalir pada alat uji daya alir. Laju alir juga dipengaruhi oleh sudut diam, dimana pengujian sudut diam granul termasuk dalam kategori baik. Evaluasi sudut diam berkaitan dengan sifat kohesif antar granul. Semakin datar tumpukan granul maka semakin kecil kemiringannya sehingga granul dapat mengalir dengan kecepatan dan jumlah yang konstan. Pada evaluasi kompresibilitas granul, dihasilkan hasil pengujian dengan 100 ketukan pada ketiga formula (10,11\%; 8,99\%; 13,33\%), dimana hasil pengujian tersebut termasuk kategori sangat baik. Kompresibilitas granul yang baik disebabkan karena penggunaan PVP sebagai bahan pengikat basah menjadikan granul yang terbentuk memiliki daya ikat antar partikel dan kekompakan granul yang baik. Sehingga pada saat pemberian tekanan pada granul saat pencetakan, kekompakan dan kerapatan granul tetap terjaga sehingga menghasilkan tablet yang kompak dimana hasil evaluasi tablet terutama evaluasi kekerasan dan friabilitas tablet memberikan hasil yang sesuai persyaratan.

Sementara dalam penelitian Pituanan dan Surini ${ }^{27}$ mengenai formulasi tablet dari ekstrak Jahe (Zingiber Officinale Rosc.) dengan metode kempa langsung, digunakan eksipien: Co-PCS-AG (pengisi), Avicel 102 (pengikat), Manitol (pemanis) dan Aspartam, dengan memvariasikan pengisi dan dibuat menjadi 5 formula. Hasil evaluasi laju alir granul menunjukkan hasil bahwa granul termasuk kategori sangat kohesif (hasil pengujian pada rentang 0,95-1,18 gr/detik). Sementara hasil pengujian kompresibilitas menunjukkan hasil kelima formula berada pada rentang nilai $21,10-21,73 \%$, dan termasuk kategori kurang. Pada pengujian sifat fisik tablet menunjukkan hasil pengujian friabilitas tablet pada kelima formula berada pada rentang nilai lebih dari $1 \%$ dan berada dalam kategori kurang. Kurang baiknya hasil evaluasi sifat fisik granul maupun tablet pada formula dapat disebabkan oleh perbandingan jumlah zat aktif yang digunakan dengan bobot total tablet (100 mg:200 mg). Sehingga penggunaan eksipien untuk mendukung zat aktif ekstrak menjadi terbatas dan eksipien yang digunakan kurang mampu menutupi kekurangan sifat dari ekstrak jahe sebagai zat aktif. Dimana pada zat aktif berupa ekstrak biasanya memiliki sifat alir dan kompresibilitas yang kurang baik.

Dalam formulasi tablet yang menggunakan kombinasi ekstrak, Rustianti38 membuat formulasi tablet dengan kombinasi ekstrak daun salam (Eugenia Polyantha) dan herba seledri (Apium Graveolens). Pembuatan tablet dilakukan dengan menggunakan metode granulasi basah dengan membuat 3 jenis formula dan memvariasikan pengikat yang digunakan (PVP K-30, Na-CMC, Gelatin). Dimana formula 1 (F1) menggunakan pengikat PVP K-30 4\%, F2 menggunakan Na- CMC 4\%, F3 menggunakan gelatin 4\%. Variasi formula bertujuan untuk mengetahui pengikat mana yang menghasilkan hasil uji evaluasi terbaik. PVP K-30 merupakan pengikat yang larut dalam air dan pelarut polar, sehingga mampu membentuk ikatan granul yang kuat (Kibbe, 2000). 
Na-CMC merupakan pengikat yang mampu meningkatkan daya ikat antar partikel sehingga dapat meningkatkan kekerasan tablet yang dihasilkan dan memperlama waktu hancur. Na-CMC digunakan sebagai pengikat dengan konsentrasi $1-6 \%{ }^{41}$. Sedangkan gelatin sebagai bahan pengikat dapat digunakan pada senyawa yang sulit diikat, akan tetapi cenderung menghasilkan tablet yang keras sehingga menghasilkan tablet dengan waktu hancur yang lama (Lachman, 1994). Maka dari itu digunakan Acdi-sol sebagai super-disintegrant sehingga tablet memiliki waktu hancur sesuai persyaratan namun tetap memiliki daya ikat antar partikel yang kuat.

Variasi formula bertujuan untuk mengetahui pengikat mana yang menghasilkan hasil uji evaluasi terbaik. Selain itu juga dilakukan uji stabilitas tablet untuk mengetahuin mutu tablet selama masa penyimpanan pada suhu kamar selama 2 bulan. Dari hasil evaluasi mutu granul dan tablet, ketiga formula menghasilkan hasil evaluasi yang memenuhi syarat dan tidak jauh berbeda antar formula. Namun dalam pengujian stabilitas tablet, dalam pengujian friabilitas didapatkan hasil pengujian dimana formula 2 (pengikat CMC) tidak memenuhi syarat friabilitas tablet. Sehingga dapat disimpulkan formula yang terbaik adalah formula dengan variasi pengikat PVP K-30.

Dalam penelitian yang dilakukan oleh Yulianita ${ }^{39}$ menggunakan kombinasi ekstrak ekstrak teh hijau, pegagan dan jahe merah sebagai zat aktif dalam sediaan tablet hisap. Pembuatan tablet menggunakan metode granulasi basah dan dibuat 4 formula dengan variasi pemanis yang digunakan ( $\mathrm{Na}$ siklamat, Nipagin-Nipasol). Sedangkan bahan pengikat (gom arab), pengisi (laktosa) dan pelincir (Mg stearate-Aerosil) yang digunakan pada masing-masing formula memiliki jumlah yang sama. Hasil penelitian menunjukkan bahwa pada pengujian evaluasi mutu tablet, diketahui formula 1 dan 2 (variasi pemanis $\mathrm{Na}$ siklamat $0,5 \%$ ) menghasilkan hasil uji yang memenuhi syarat. Sementara pada variasi formula 3 dan 4 (variasi Na siklamat 1\% dan 2\%) menghasilkan hasil uji yang tidak memenuhi syarat, yaitu pada pengujian kekerasan tablet. Dimana penyebab kekerasan tablet pada formula 3 dan 4 yang tidak memenuhi syarat yaitu tidak optimalnya pengoperasian dari mesin pencetak tablet yang menyebabkan ketidakseragaman bobot dan kekerasan tablet. Sementara dalam uji kesukaan (hedonic) yang dilakukan terhadap 20 orang responden, didapatkan hasil bahwa formula 4 dengan variasi Na siklamat $4 \%$ merupakan tablet yang paling disukai secara rasa dibandingkan dengan formula lainnya. Karena pemanis Natrium siklamat merupakan pemanis yang sering digunakan dalam produk makanan maupun minuman dan memiliki tingkat kemanisan 30-50 kali lebih tinggi dibandingkan gula, meskipun memiliki efek karsinogenik yang berbahaya bila digunakan melebihi batas.

Selain hal yang telah disebutkan di atas, pertimbangan dalam pemilihan metode dalam formulasi tablet juga disesuaikan dengan sifat dari masing-masing tanaman yang dibuat tablet. Dimana untuk ekstrak tanaman yang tahan terhadap pemanasan dan memiliki laju alir buruk, pembuatan tablet dilakukan dengan metode granulasi basah. Untuk ekstrak tanaman yang tidak tahan terhadap pemanasan (termolabil) pembuatan tablet dilakukan dengan metode kempa langsung. Eksipien yang digunakan juga disesuaikan dengan metodenya. Dimana untuk metode granulasi basah, digunakan pengikat basah seperti: akasia, PVP dan CMC. Sedangkan pengikat yang sering digunakan pada metode kempa langsung yaitu Avicel. 
Bahan pelincir yang sering digunakan dalam pembuatan tablet, baik dengan metode granulasi maupun kempa langsung, adalah campuran magnesium stearate dan talcum. Penggunaan keduanya dimaksudkan untuk memperbaiki dan menutupi kekurangan masing-masing bahan. Penggunaan magnesium stearate sebagai lubrikan dimaksudkan untuk meminimalkan gesekan antara granul dengan dinding die pada mesin cetak saat akan dilakukan pencetakan tablet, dan penggunaan talcum sebagai glidan dimaksudkan agar memudahkan aliran dan ikatan antar partikel granul saat pencetakan.

Penggunaan pengisi bertujuan untuk memenuhi massa dan kekompakan tablet sehingga tablet dapat dicetak. Pengisi yang sering digunakan dalam pembuatan tablet yaitu amilum dan laktosa, dimana amilum juga dapat berperan sebagai disintegrant (penghancur) dengan konsentrasi tertentu. Penggunaan pengisi harus memenuhi beberapa aspek, diantaranya: harga yang ekonomis, dapat mendukung pelepasan zat aktif, dan tidak mempengaruhi efek dari zat aktif (inert).

Pertimbangan pemilihan eksipien diantaranya: eksipien harus tidak mengganggu kerja dari zat aktif (inert); harga ekonomis; tidak berbau, tidak berwarna dan berasa; dan dapat memperbaiki dan melengkapi kekurangan dari zat aktif maupun eksipien lainnya. Pemilihan eksipien juga disesuaikan dengan zat aktif, dimana eksipien yang dipilih harus dapat menutupi sifat kekurangan dari zat aktif, sehingga granul yang terbentuk memiliki sifat fisik yang baik.

\section{Kesimpulan}

Penggunaan zat aktif berupa herbal dimaksudkan sebagai alternatif pengobatan terhadap obat dengan zat aktif kimia. Tablet merupakan sediaan obat yang banyak digunakan karena dosisnya yang tepat dan mudah digunakan. Pembuatan tablet dilakukan dengan tiga metode utama, yaitu: granulasi basah, granulasi kering dan kempa langsung. Berdasarkan penelusuran pustaka yang dilakukan, pembuatan tablet dengan bahan aktif ekstrak banyak dilakukan dengan metode granulasi basah, karena kebanyakan ekstrak memiliki laju alir dan kompresibilitas yang kurang baik. Maka dari itu digunakan pengikat basah untuk memperbaiki sifat dari ekstrak. Metode kempa langsung, terutama pada tablet dengan dosis zat aktif tinggi, sifat fisik tabletnya terutama dipengaruhi oleh sifat dari ekstrak sebagai zat aktif. Sehingga keberadaaan eksipien kurang mampu untuk menutupi kekurangan dari zat aktif. Di samping itu, pemilihan metode formulasi juga disesuaikan dengan sifat ekstrak dan eksipien yang akan digunakan. Sementara pemilihan eksipien disesuaikan dengan sifat zat aktif dan metode formulasi yang akan digunakan. 


\section{Daftar Pustaka}

1. Qato DM, Alexander GC, Conti RM, Johnson M, Schumm P, Lindau ST. Use of Prescription and Over-The-Counter Medications and Dietary Supplements among Older Adults in The United States. JAMA. 2008; 300: 2867-78.

2. Cohen PA and Ernst E. Safety of Herbal Supplements: A Guide for Cardiologists. Cardiovasc Ther. 2010; 28: 246-53.

3. Banker SG and Anderson RN. Tablet in Lachman, L; Lieberman, the Theory and Practice of Industrial Pharmacy $3^{\text {rd }}$ ed. Philadelphia: Lea and Febiger. 1986.

4. Lachman L, Lieberman HA, Kanig JL. Teori dan Praktek Farmasi Industri Edisi II (diterjemahkan oleh Suyatni S). Jakarta: UI Press; 1994.

5. Walid FS. Upgrading Wet Granulation Monitoring from Handsqueeze Test to Mixing Torque Rheometry. Saudi Pharmaceutical Journal. 2012; 20: 9-19.

6. Murtini G dan Elisa Y. Teknologi Sediaan Solid. Jakarta: Kementrian Kesehatan Republik Indonesia. 2018: 246-251.

7. Shirode, R. and Gorle, A. 2016. A Review: Granulation Technology For Pharmaceutical Product Development. World Journal of Pharmaceutical Research. Volume 5, Issue 6, 729-740.

8. Hidayah N. Formulasi Tablet Ekstrak Daun Maja (aeglemarmelos I. Correa) Dengan Metode Granulasi Basah. Journal of Pharmaceutical Science and Herbal Technology 2016; 1(1): 36-40.

9. Suyono E dan Nurhaini R. Formulasi Tablet Ekstrak Kunyit (Curcuma Domestica Val) Dengan Variasi Bahan Pengikat. CERATA Journal of Pharmacy Science. 2014: 5(1): 1-16.

10. Rori WM, Yamlean PVY, dan Sudewi S. Formulasi dan Evaluasi Sediaan Tablet Ekstrak Daun Gedi Hijau (Abelmoschus manihot) Dengan Metode Granulasi Basah. PHARMACON Jurnal IImiah Farmasi-UNSRAT. 2016; 5(2): 243-50.

11. Mustarichie R dan Priambodo D. Tablet Formulation from Meniran (Phyllanthus Niruri L.) Extract with Direct Compression Method. International Journal of Applied Pharmaceutics. 2018; 10(4): 98-102.

12. Herawati M, Syukri Y, dan Chabib L. Formulasi Tablet Ekstrak Daun Pepaya (Carica papaja L.) dengan Bahan Pengikat Polyvinylpyrrolidone (PVP). Jurnal Pharmascience. 2014; 1(2): 67 - 75.

13. Astuti RD dan Sriwijayanti G. Formulasi dan Evaluasi Tablet Kunyah Ekstrak Buah Ketumbar (Coriandrum sativum. L) Dengan Kombinasi Manitol dan Laktosa Sebagai Bahan Pengisi. Jurnal Kesehatan. 2016; 11(2): 338-347.

14. Hanum TI dan Lestari SI. Formulasi Tablet Hisap Ekstak Etanol Daun Randu (Ceiba Pentandra L Gaertn) Menggunakan Carboxy Methyl Cellulose (CMC) Sebagai Bahan Pengikat Dengan Metode Granulasi Basah. TM Conference Series 2018; 01: 46-51.

15. Kharisma R, Sari IP, dan Bestari AN. Optimasi Formula Tablet Ekstrak Umbi Bengkuang (Pachyrrhizus erosus) dengan Variasi Komposisi Bahan Pengisi Avicel ${ }^{\circledR}$ pH 101 dan Bahan Penghancur Crospovidone. Traditional Medicine Journal. 2018; 23(1): 9-15. 
16. Rustiani E, Andini S, dan Musnawati. Formulasi Fast Desintegrating Tablet (FDT) Sari Buah Jambu Biji Merah dengan Perbedaan Konsentrasi Ac-Disol. Pharmaceutical and Biomedical Sciences Journal. 2019; 1(1): 13-20.

17. Winarti W, Kartiningsih, Djamil R, Zaidan S, Nugrahaini I. Formulasi Sediaan Tablet Ekstrak Sambung Nyawa (Gynurae procumbens (Lour).Merr) sebagai Kandidat Antidiabetes. Jurnal Ilmu Kefarmasian Indonesia. 2016; 14(2): 240-245.

18. Fadhilah IN dan Saryanti D. Formulasi Dan Uji Stabilitas Fisik Sediaan Tablet Ekstrak Buah Pare (Momordica charantia L.) Secara Granulasi Basah. Smart Medical Journal. 2019; 2(1): 25-31.

19. Syukri Y, Wibowo JT, dan Herlin A. Pemilihan Bahan Pengisi untuk Formulasi Tablet Ekstrak Buah Mahkota Dewa (Phaleria macrocarpa Boerl). Jurnal Sains Farmasi \& Klinis. 2018; 5(1): 66-71.

20. Mindawarnis dan Hasanah D. Formulasi Sediaan Tablet Ekstrak Daun Nangka (Artocarpus heterophyllus L.) Dengan Variasi Polivinil Pirolidon (PVP) Sebagai Pengikat dan Evaluasi Sifat Fisiknya. Jurnal Kesehatan Palembang. 2017; 12(1): 1226.

21. Haryanti F, Purwantini I, dan Sulaiman TNS. Formulasi Tablet Hisap Ekstrak Kunyit (Curcuma domestica) Dengan Kombinasi Bahan Pengisimanitol - Amilum Manihot. Majalah Obat Tradisional. 2012; 17(3): $47-52$.

22. Sugiyono, Iftitah AOE, dan Windriyati YN. Optimasi Formula Tablet Ekstrak Daun Sirih Merah (Piper crocotum Ruiz \& Pav) dengan Metode Kempa Langsung Menggunakan Desain Faktorial. Majalah Farmasi, Sains, dan Kesehatan Pharmauho. 2016; 2(1): 6-9.

23. Winanta A, Syukri Y, dan Chabib L. Formulasi Tablet Ekstrak Buah Naga (Hylocereus polyrhizus) Mengunakan Amilum Ubi Jalar Pregelatinasi Sebagai Bahan Penghancur. Medical Sains. 2019; 3(2): 105-118.

24. Yunarto N. Formulation of Peperomia pellucida (L) Kunth Extract Tablet by Modified Filler. Health Science Indones. 2013; 4(1): 32-6.

25. Damayanti IPS, Sulaiman TNS, Bestari AN, dan Setiawan IM. The Formulation of Pacing (Costus speciosus) Extract Tablet by Using Avicel®PH 200 As Filler-Binder and Amylum as Disintegration Agent. Indonesian J. Pharm. 2018; 29(1): 29-36

26. Tayb HAM, Karim AKMA, and Ghada MEA. Formulation and Evaluation of Lepidium Sativum Seeds Extract as Diuretic Tablet dosage form. American Journal of Research Communication. 2015; 3(7): 196-217.

27. Pituanan BS and Surini S. Fast-Disintegrating Tablet Formulation of Ginger (Zingiber Officinale Rosc.) Extract Using Coprocessed Excipient of Pre-Gelatinized Cassava Starch-Acacia Gum. Int J App Pharm. 2017; 9(1): 154-8.

28. Srivastava S, Panda P, Vishwakarma DK, Verma NK, and Nayak J. Formulation and Evaluation of Herbal Tablets Containing Agaricus bisporus Powder. International Journal of Advances in Pharmaceutics. 2017; 6(2): 63-69.

29. Khaidir S, Murrukmihadi M, dan Kusuma AP. Formulasi Tablet Ekstrak Kangkung Air (Ipomoea aquatica F.) Dengan Variasi Kadar Amilum Manihot Sebagai Bahan Penghancur. Jurnal IImiah Farmasi. 2015; 11(1): 1-8. 
30. Jannah RN, Fadraersada J, Meylina L dan Ramadhan AM. 2018. Formulasi Granul Antioksidan Ekstrak Etanol Daun Sirsak (Anonna muricata Linn.) Menggunakan Metode Granulasi Basah. Proceeding of the 8th Mulawarman Pharmaceuticals Conferences. 2016; 97-103.

31. Rabbani F, Husni P, dan Hartono K. Formulasi Tablet Hisap Ekstrak Kering Daun Sirih Hijau (Piper betle L). Farmaka. 2017; 15(1): 185-99.

32. Ameliana L dan Wazni F. Pengaruh Akasia Sebagai Bahan Pengikat Terhadap Mutu Fisik Tablet Hisap Ekstrak Teh Hijau (Camellia sinensis). J. Trop. Pharm. Chem. 2011; 1(3): 207-220.

33. Ariswati WC, Siswanto A, Hartanti D. Pengaruh Gelatin, Amilum Dan PVP Sebagai Bahan Pengikat Terhadap Sifat Fisik Tablet Ekstrak Temulawak (Curcuma XanthorrhizaRxob). PHARMACY. 2010; 7(2): 58-66.

34. Rusita YD. Optimasi Campuran Manitol-Sukrosa Untuk Tablet Hisap Ekstrak Daun Dewa (Gynura procumbens (Lour.) Merr.) Secara Granulasi Basah Dengan Metode Simplex Lattice Design. Jurnal Kebidanan Dan Kesehatan Tradisional. 2016; 1(1): 48-54.

35. Pradiningsih A, Dimpil dan Hardiyanti N. Pengujian Karakteristik Fisik Tablet Ekstrak Buah Jambu Biji (Psidium Guajava) Dengan Penambahan Bahan Penghancur Sodium Starch Glycolate (SSG) Secara Granulasi Basah. Journal of Pharmacopolium. 2019; 2(2): 122-129.

36. Panatta R, Hertiani T, dan Mufrod. Formulasi Tablet Effervescent Ekstrak Etanolik Buah Mengkudu Menggunakan Variasi Komposisi Sumber Asam (Effervescent tablet formulation from ethanolic estract of mengkudu fruit by variations of acid source composition). Jurnal Tumbuhan Obat Indonesia. 2011; 4(1): 48-57.

37. Ringoringo VS dan Choiriyah. Formulasi Tablet Kunyah Ekstrak Akar Manis (Succus Liquiritae) Dengan Kombinasi Bahan Pengisi Sorbitol-Laktosa Terhadap Pengaruh Sifat Fisik Tablet Kunyah Menggunakan Metode Kempa Langsung. Indonesia Natural Research Pharmaceutical Journal. 2018; 3(1): 58-63.

38. Rustianti E, Miranti M, dan Susanti AS. Sediaan Tablet Kombinasi Ekstrak Daun Salam (Eugenia Polyantha) Dan Herba Seledri (Apium Graveolens) Dengan Variasi Jenis Pengikat. Fitofarmaka Jurnal Ilmiah Farmasi. 2019; 2(9); 86-95.

39. Yuliania. Formulasi Tablet Hisap Kombinasi Ekstrak Teh Hijau, Pegagan Dan Jahe Merah Dengan Variasi Konsentrasi Na-Siklamat. Jurnal IImiah Farmasi Unpak. 2014.

40. Sulaiman TN, Sulaiman S. EKSIPIEN UNTUK PEMBUATAN TABLET DENGAN METODE KEMPA LANGSUNG. Journal of Pharmaceutical And Sciences. 2020 Nov $11 ; 3(2): 64-76$.

41. Hooton JC. Carboxymethylcellulose Sodium, Dalam Rowe, R. C. Sheskey P. J. dan Quinn M. E., (Eds.), Handbook of Pharmaceutical Excipient Sixth edition, Pharmaceutical Press, London, 2009. p. 118-121. 